\title{
Direct Spectrophotometric Determination of Lead (II) in Industrial Samples using 1, 3-Benzenediamine, N, N'-bis(2- furanylmethylene) in Presence of Surfactant
}

\author{
Zaky M. ${ }^{a}$, Amin A. S. ${ }^{b}$, Elgendy Kh. ${ }^{a}$ and Gomaa A. \\ ${ }^{\text {a }}$ Chemistry Department Faculty of Science, Zagazig University, Zagazig, Egypt. \\ ${ }^{\mathrm{b}}$ Chemistry Department Faculty of Science, Banha University, Banha, Egypt. \\ *Corresponding author \\ Dr.Khaled Mansour Elgendy \\ El_gendykh@yahoo.com \\ Tel.+201005169453
}

\begin{abstract}
Schiff's base are one of the excellent chelating agents that used for the spectrophotometric determination of metal ions. It was observed that 1, 3Benzenediamine, N,N'-bis(2-furanylmethylene) (BDFM) formed a brown colored complex with lead (II) at $620 \mathrm{~nm}$. Lead (II) was chelated with the Schiff's base (BDFM) in acidic medium at $\mathrm{pH}=3.5$ using acetate buffer in presence of sodium laureth sulfate (SLS) as a surfactant. The effect of time, temperature and foreign ions were studied. The stoichiometric composition of the formed complex was found to be 1:2 (metal: ligand) by Job's method of continuous variation. Beer's law was obeyed in the range of $10-110 \mu \mathrm{g} \mathrm{mL}^{-1}$ with molar absorptivity $10.16 \times 10^{3} \mathrm{~L} \mathrm{~mol}^{-1} \mathrm{~cm}^{-1}$. The proposed method was applied for the determination of lead in gasoline, solders, gutters and wastewater.
\end{abstract}

Keywords: Spectrophotometry, lead (II), 1, 3-Benzenediamine, N, N'-bis (2furanylmethylene) (BDFM), SLS, Beer's law, Industrial samples.

\section{Introduction}

Schiff's bases have been known since 1864 when Hugo Schiff reported the condensation of primary amines with carbonyl compounds [1].

Schiff's bases are typically formed by the condensation of a primary amine and an aldhyde [2]. Schiff's bases and their metal complexes are known to exhibit anticancer, antioxidant and anti-inflammatory activities [3]. Transition metal Schiff's base complexes are used in various fields, such as medicine, 
agriculture, industries etc. [4]. The Schiff's bases have been effectively used as analytical reagents for extractive spectrophotometric determination of metal ions, as they possess excellent chelating properties [5].

Lead compounds are used in different industries worldwide due to their chemical and physical characteristics [6]. Lead is a cumulative poison that enters the body from lead water pipes, lead-based paints and leaded petrol. Presence of even traces of $\mathrm{Pb}$ (II) in environmental samples leads to environmental pollution and many fatal diseases including dysfunction of renal blood and neurological systems [7]. The toxicity of lead has been studied extensively. Lead poisoning in humans causes severe damage in the kidneys, liver, brain, reproductive system, and central nervous system, and sometimes causes death [8].

Lead is used in the preparation of acid storage batteries, ammunition, solder, sheet lead and tern steel. It is also used in the preparation of tetraethyl lead which is used as an antiknock agent in gasoline. Due to relatively low cost and excellent versatility, lead compounds are used as anticorrosive and highway traffic safety paints [9]. Lead determination is very important in the context of environmental monitoring however a large number of spectrometric methods for determination of lead are reported to face interference due to the presence of several metal ions [10].

In waters, lead is usually determined by flame atomic absorption spectrometry (FAAS), electrothermal atomic absorption spectrometry (ETAAS), inductively coupled plasma-atomic emission spectrometry (ICP-AES), usually requiring a pre-concentration step, inductively coupled plasma-mass spectrometry (ICP-MS), and the colorimetric method based on dithizone [11]. Atomic absorption spectrometry was used as the developed method has been applied for the determination of lead (II) appearing as impurities in pharmaceutical substances [12].

A large number of simple sensitive spectrophotometric methods are used for determination of lead by some different reagents such as alizarine yellow [13], dichlorohydroxyl phenyl porphyrin [14], 3-hydroxy-3-p tolyl-1-o chloro phenyl triezene [15], alizarin red [16], N-(2'-Pyridyl)-4- hydroxybenzamide [17] and 4-(2-Pyridylazo)-Resorcinol [18]. These method offer the advantage of simplicity, rapidity, high sensitivity and direct determination of lead [19].

\section{Experimental}

\section{Apparatus}

T80 UV/Vis. Double beam spectrophotometer, PG instruments Ltd Company, United Kingdom was used for absorbance measurements and $\mathrm{pH}$ adjustment was carried out using (Adwa pH-meter, Model AD 1030, Romania) fitted with a combination glass-calomel electrode. 


\section{Chemicals}

All chemicals used were of analytical reagent grade (AR), and of highest purity available. They included:

\begin{tabular}{cccc}
\hline Chemical & Company & Chemical & Company \\
\hline Furan-2-carbaldhyde & Merk & Sodium acetate & Sigma \\
Benzene-1,3-amine & Sigma & Borax & Prolabo \\
Lead acetate & Merk & Boric acid & Merk \\
Acetic acid & Sigma & SLS & Prolabo \\
CTAB & Sigma & Methanol (90\%) & Prolabo \\
Triton x100 & Sigma & Ethylene glycol. & Prolabo \\
Ethyl alcohol $(90 \%)$ & Prolabo & Glycerine & Prolabo \\
Dimethylsulfoxide & Prolabo & Acetone & Prolabo \\
\hline
\end{tabular}

Deionized water was usually used in all preparations.

Ligand reagen: Stock solution $(100 \mathrm{~mL})$ of ligand reagent of concentration $\left(1 \times 10^{-2} \mathrm{M}\right)$ was prepared by dissolving the appropriate amount $(0.264 \mathrm{~g})$ of ligand reagent in least amount of DMF as a solvent and complete to $100 \mathrm{~mL}$ with deionized water.

Standard lead solution: lead (II) stock solution of $0.001 \mathrm{M}$ was prepared by dissolving $0.0325 \mathrm{~g}$ of $\left[\mathrm{Pb}\left(\mathrm{CH}_{3} \mathrm{COO}\right)_{2}\right]$ in $100 \mathrm{~mL}$ of deionized water and solutions of lower concentrations were prepared from the stock solution by dilution and the solution was standardized by EDTA [20].

Surfactant solutions: The surfactants, Sodium laureth sulfate (SLS), Triton X 100 and Cetyl trimethyl ammonium bromide (CTAB) were prepared at concentration $\left(1 \times 10^{-2} \mathrm{M}\right)$ by dissolving the calculated amounts in deionized water and used without further purification.

\section{Buffer solutions}

For the preparation of buffer solutions, different types of buffers including acetate buffer in the range of (3.5-6), universal buffer (1.81-11.98) [21], borate buffer (7.6-10) [22], citrate buffer (3-6), phosphate buffer (7-11) and acetate buffer (3.5-6) [23] were prepared.

\section{Procedures}

\section{Preparation of Schiff's base}

A mixture of substituted benzene-1,3-amine $(10 \mathrm{mmol})(1.08 \mathrm{~g})$ and furan-2carbaldhyde $(20 \mathrm{mmol})(1.65 \mathrm{ml})(\mathrm{d}=1.16)$ were dissolved in $10 \mathrm{~mL}$ absolute ethanol. The mixture was refluxed for 5 hours. It was then cooled and diluted with ice cold water. The resulting solid was recrystallized from ethanol to the proposed Schiff bases. 
<smiles>Nc1cccc(N)c1</smiles>

benzene-1,3-diamine furan-2 carbaldehyde 1,3-Benzenediamine, N,N'-bis (2-furanylmethylene)

\begin{tabular}{|c|c|}
\hline Chemical Formula & $\mathrm{C}_{16} \mathrm{H}_{12} \mathrm{~N}_{2} \mathrm{O}_{2}$ \\
\hline Exact Mass & $264.09 \mathrm{~g} / \mathrm{mol}$ \\
\hline Systematic name & 1,3 -Benzenediamine, $\mathrm{N}, \mathrm{N}^{\prime}$-bis(2-furanylmethylene) \\
\hline Molecular Weight & $264.28 \mathrm{~g} / \mathrm{mol}$ \\
\hline $\mathbf{m} / \mathbf{z}$ & $264.09(100.0 \%), 265.09(18.1 \%), 266.10(1.4 \%)$ \\
\hline Elemental Analysis & $\mathrm{C}, 72.72 ; \mathrm{H}, 4.58 ; \mathrm{N}, 10.60 ; \mathrm{O}, 12.11$ \\
\hline
\end{tabular}

\section{Preparation of solid complex}

The complex was prepared by addition of $10 \mathrm{~mL}$ hot solution $(0.1 \mathrm{M})$ lead acetate $\left[\left(\mathrm{Pb}\left(\mathrm{CH}_{3} \mathrm{COO}\right)_{2}\right)\right]$ to $20 \mathrm{~mL}$ hot solution $\left(40^{\circ} \mathrm{C}\right)$ of the Schiff's base BDFM $(0.1 \mathrm{M})$ with $3.00 \mathrm{~mL}$ of acetate buffer $\mathrm{pH}=3.5$. The resulting mixture was stirred under reflux for 1.0 hour where up on the complex precipitated. This was collected by filtration, washed with $10 \mathrm{ml}$ a $1: 1$ ethanol-water mixture and finally by $10 \mathrm{ml}$ diethyl ether.

\section{Absorptioncurve}

Transfer a $1.00 \mathrm{~mL}$ of $\mathrm{Pb}$ (II) solution $\left(1 \times 10^{-3} \mathrm{M}\right), 2.00 \mathrm{~mL}$ of reagent solution $\left(1 \times 10^{-2} \mathrm{M}\right)$ and $3.00 \mathrm{~mL}$ acetate buffer $\mathrm{pH}=3.5$ into $10 \mathrm{~mL}$ measuring flask and complete to the mark with deionized water. At once, the maximum absorbance was measured by scanning wavelength from 200 to $800 \mathrm{~nm}$ against the reagent blank.

\section{In presence of surfactant}

In presence of $1.00 \mathrm{~mL}$ surfactant SLS solution $\left(1 \times 10^{-2} \mathrm{M}\right)$ take $1.00 \mathrm{~mL}$ of $\mathrm{Pb}$ (II) $\left(1 \times 10^{-3} \mathrm{M}\right), 2.00 \mathrm{~mL}$ of reagent solution $\left(1 \times 10^{-2} \mathrm{M}\right)$ and $3.00 \mathrm{~mL}$ acetate buffer $\mathrm{pH}=3.5$ were mixed in $10 \mathrm{~mL}$ measuring flask and complete to the mark with $3.00 \mathrm{~mL}$ deionized water. At once, the absorbance for the sample was measured by scanning wavelength from 200 to $800 \mathrm{~nm}$ against the reagent blank.

\section{Beer's law}

A series of solutions containing a known volume of ligand reagent and different concentration of $\mathrm{Pb}$ (II) ranging from $10-110 \mu \mathrm{g} \mathrm{mL}^{-1}$, were mixed in $10 \mathrm{~mL}$ voltametric flask, with known volume of acetate buffer $\mathrm{pH}=3.5$ and $1.00 \mathrm{~mL}$ SLS at once at $30^{\circ} \mathrm{C}$, the absorbance was measured at $620 \mathrm{~nm}$ against blank solution for $\mathrm{Pb}$ (II). 


\section{Applications}

\section{A-Determination of $\mathbf{P b}$ (II) in solders}

A weighed sample $(0.5 \mathrm{~g})$ was dissolved in $15 \mathrm{~mL}$ hydrochloric acid (1:1) with gently heating for few minutes. The solution was cooled to room temperature and filtered. The solution was diluted to $100 \mathrm{~mL}$. The above solution was mixed with ligand reagent, mask cupper by using sodium thio sulfate [20] and measure absorbance against blank.

\section{B-Determination of $\mathbf{P b}$ (II) in gutters}

A $1.5 \mathrm{~m}$ of gutters was dissolved in $15 \mathrm{~mL}$ concentrated hydrochloric acid with gently heating for few minutes. The solution was cooled to room temperature and filtered. The solution was diluted to $100 \mathrm{~mL}$. The above solution was mixed with ligand reagent according to the above.

\section{$\mathrm{C}$ - Determination of $\mathbf{P b}$ (II) in gasoline80}

A $2.00 \mathrm{~mL}$ of the gasoline solution was mixed with ligand reagent and the absorbance was measured at $620 \mathrm{~nm}$ against the blank according to the above procedures.

\section{D- Determination of $\mathbf{P b}$ (II) in wastewater sample}

$1.00 \mathrm{~mL}$ of the wastewater sample was mixed with ligand reagent and the absorbance was measured at $620 \mathrm{~nm}$ against the blank according to the above procedures.

\section{Results and discussion}

\section{Absorption curve}

BDFM ligand reagent was used as a new spectrophotometric reagent for the determination of lead (II) by forming brown coloured stable complex at 620 $\mathrm{nm}$ for $\mathrm{Pb}$ (II), as shown in Fig. (3), while Fig (1), Fig (2) represented the IR spectra of ligand and the complex respectively.

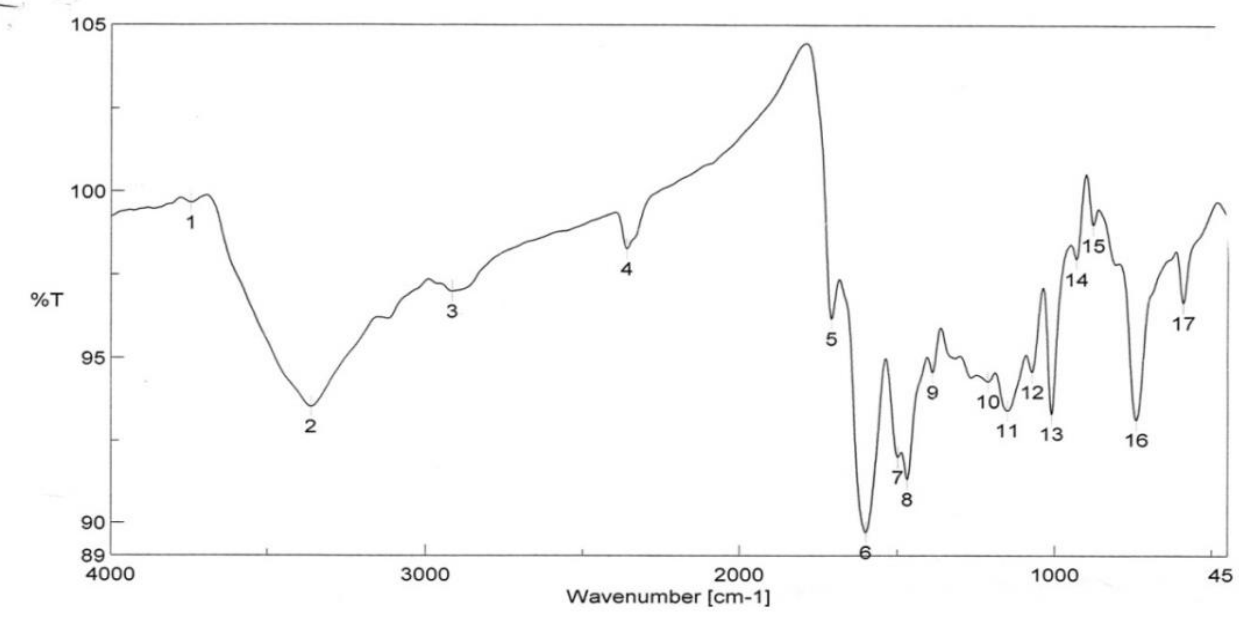

Fig (1): IR spectra of ligand (BDFM) 


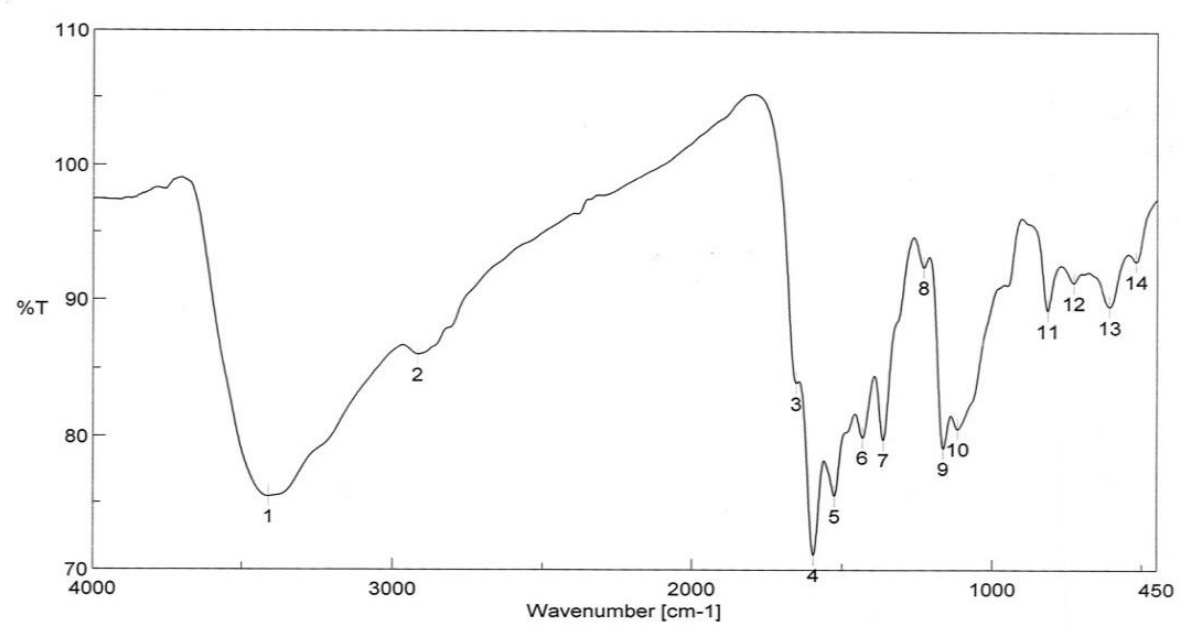

Fig (2): IR spectra of lead solid complex

\section{Effect of pH and buffer solution}

The study of the effect of $\mathrm{pH}$ on the colour intensity of the complexes showed that the appropriate $\mathrm{pH}$ range was from 1 to 5 with maximum value at $\mathrm{pH}=3.5$ for Pb-BDFM complex as shown in Fig. (4). Studying the effect of different buffer types in the range from (3-5) indicated that the maximum absorbance values were obtained using acetate buffer at $\mathrm{pH}=3.5$ for complex as shown in Fig. (5) and Fig (6).

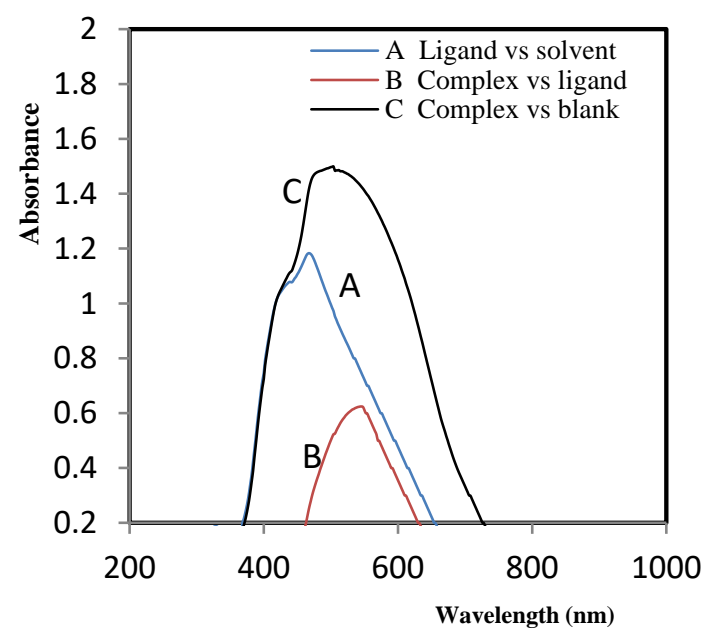

Fig (3): Absorption spectra for $\mathrm{Pb}$ (II) With BDFM complex.

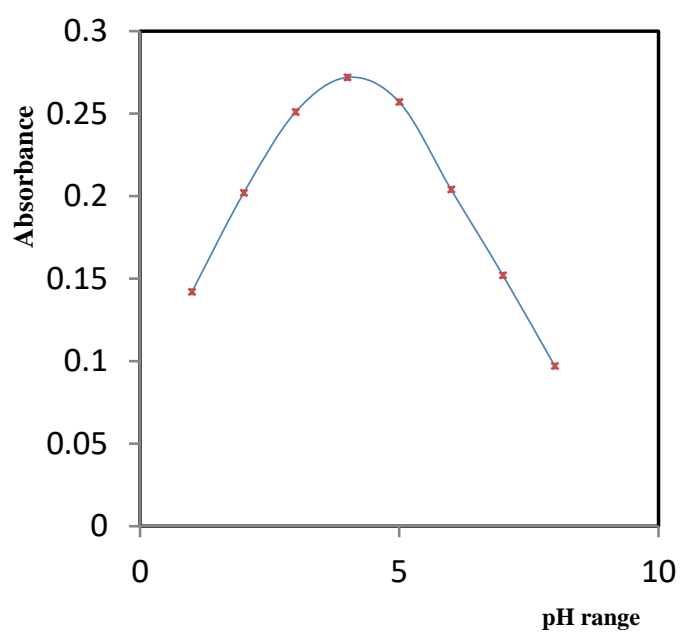

Fig (4): Effect of different $\mathrm{pH}$ on the formation for $\mathrm{Pb}$ (II) with BDFM 


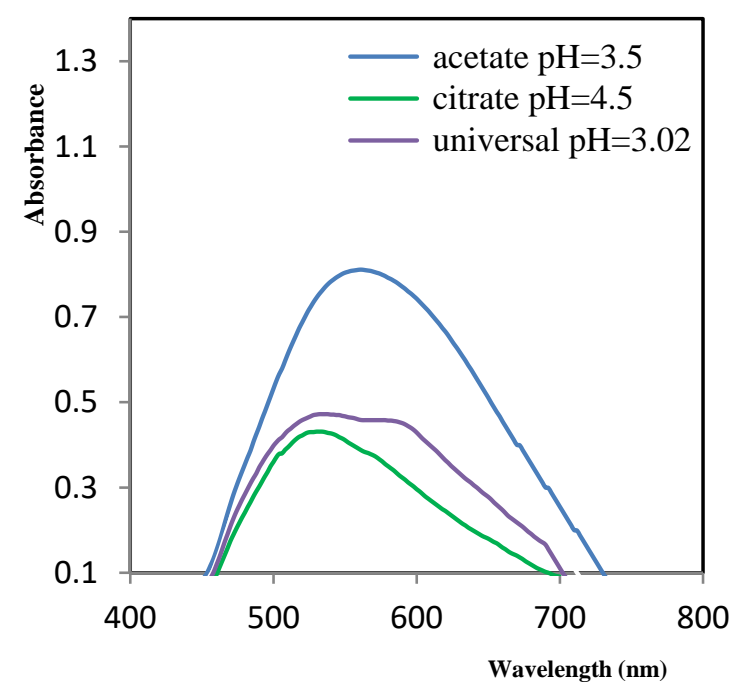

Fig (5): Effect of different buffers on the formation of $\mathrm{Pb}$ (II)-BDFM complex

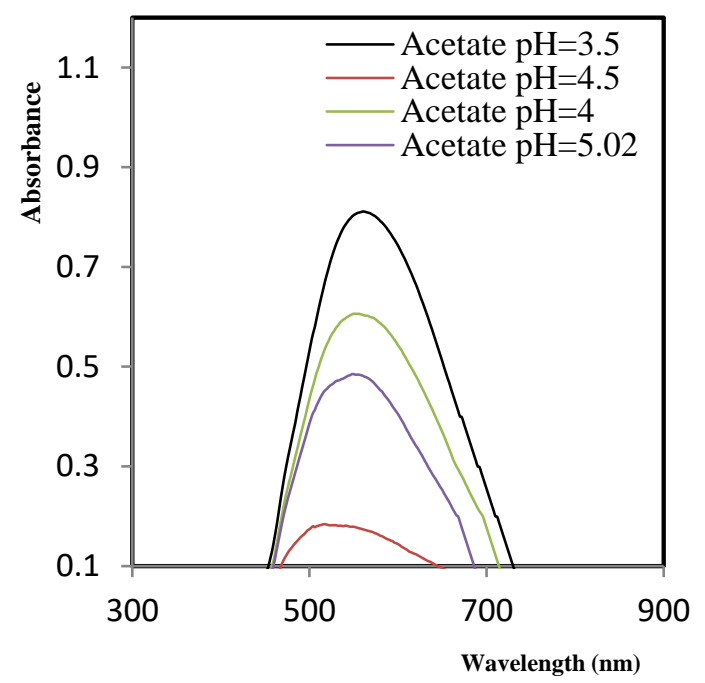

Fig (6): Effect of different acetate buffers on the formation of $\mathrm{Pb}$ (II)BDFM complex.

\section{Effect of organic solvents}

The effect of organic solvents on the absorption spectra of the formed complex was studied in methanol, ethanol, isopropanol, acetone, DMSO, glycerine, ethylene glycol and formaldehyde as solvents and the absorbance was measured in presence of other optimum conditions against the blank solution. The results illustrated that, the value of absorbance was not improved by using any organic solvents as shown in Table (1) and Fig (7):

Table (1): Effect of different solvents of and lead (II).

\begin{tabular}{ccc}
\hline Effect of solvent & $\boldsymbol{\lambda}_{\max }$ & Absorbance \\
\hline Without & 560 & 0.811 \\
Acetone & 544 & 0.561 \\
DMSO & 558 & 0.653 \\
Methanol & 572 & 0.744 \\
Ethanol & 582 & 0.765 \\
Ethylene glycol & 550 & 0.497 \\
Glycerine & 566 & 0.752 \\
Formaldhyde & 580 & 0.449 \\
Iso propyl alcohol & 558 & 0.528 \\
\hline
\end{tabular}




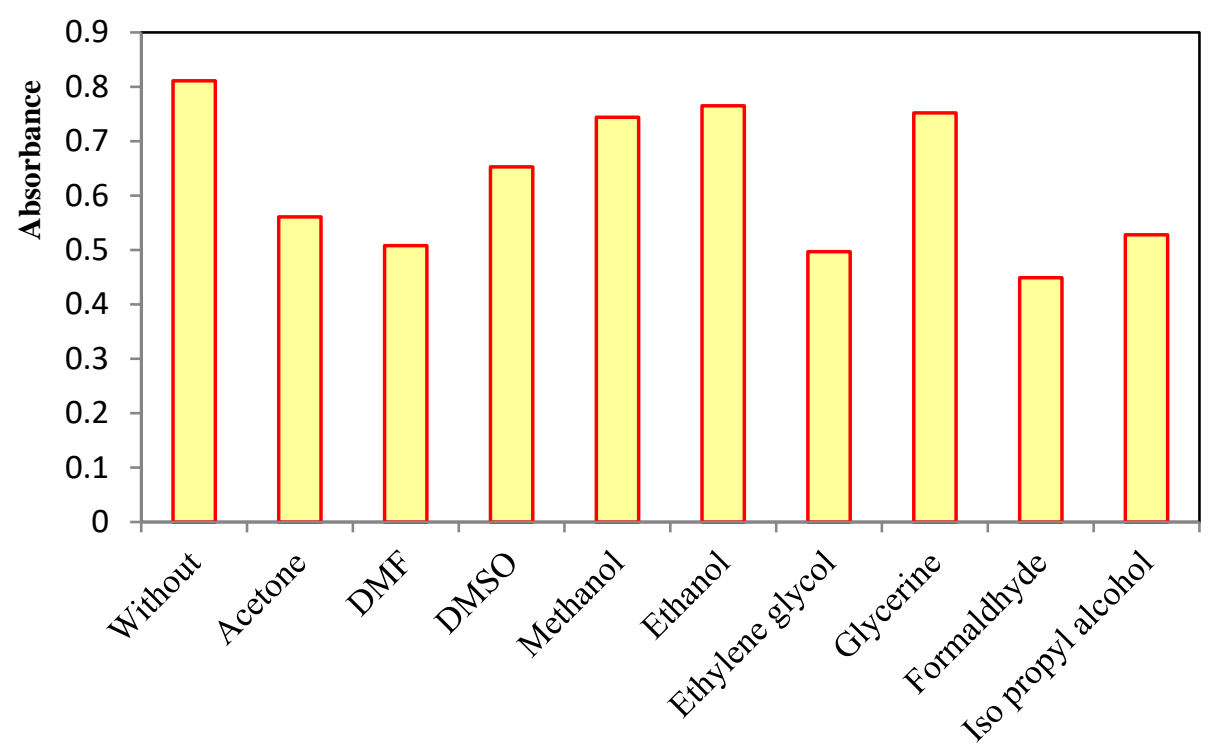

Fig (7): Effect of organic solvents.

\section{Effect of surfactants}

By studying the effect of many different surfactants such as SLS, CTAB and Triton X 100, the results showed that the presence of $1.00 \mathrm{ml}$ of SLS as a surfactant shifted the absorption peak to hyper and bathochromic shifts and this may be due to the formation of micelles or formation of double or triple complex with surfactant itself as showed in Table. (2).

Table (2): The effect of different surfactants on lead (II) complex

\begin{tabular}{|c|c|c|}
\hline Effect of surfactant & $\lambda_{\max }$ & Absorbance \\
\hline Without & 560 & 0.811 \\
\hline SLS & 620 & 0.994 \\
\hline CTAB & 612 & 0.678 \\
\hline Triton X100 & 578 & 0.756 \\
\hline
\end{tabular}

\section{Other optimum conditions}

Some other effects such as the effect of sequence of the addition, standing time and temperature were also studied on the formation of lead (II) with BDFM complex.

\section{Effect of Time}

The effect of time on the formation and color stability of $\mathrm{Pb}$ (II) - BDFM complex was studied to determine the optimum standing time for the analytical procedure by measuring the absorbance of the identical samples containing the metal ions, after intervals of time ranging between 5 and 120 minutes versus the blank. The results indicated that, $\mathrm{Pb}$ (II) - BDFM complex was instantaneously formed and remain stable for a $20 \mathrm{~h}$ as shown in Table (3) with Fig (8). 
Table (3): Time affecting on the formation of $\mathrm{Pb}$ (II) complex.

\begin{tabular}{|c|c|c|c|c|c|c|c|c|c|c|}
\hline $\begin{array}{c}\text { Time, } \\
\text { min. }\end{array}$ & $\begin{array}{c}\text { At } \\
\text { once }\end{array}$ & 5 & 10 & 15 & 30 & 45 & 60 & 75 & 90 & 120 \\
\hline Absorbance & 0.81 & 0.86 & 0.87 & 0.88 & 0.89 & 0.90 & 0.90 & 0.90 & 0.91 & 0.92 \\
\hline
\end{tabular}

\section{Effect of Temperature}

The effect of temperature was studied for the complex under investigation at different temperatures ranging from $\left(15-65^{\circ} \mathrm{C}\right)$ by heating or cooling the sample and the blank in water or ice bath, then the absorbance was measured against the reagent blank. It was found that, the maximum stability of the complex at $25^{\circ} \mathrm{C}$ and then decrease gradually by raising the temperature as shown in Table (4) with Fig (9).

Table (4): Temperature affecting on the formation of $\mathrm{Pb}$ (II) complex

\begin{tabular}{|c|c|c|c|c|c|c|c|}
\hline Temperature,$^{\circ} \mathbf{C}$ & 20 & 25 & 35 & 45 & 55 & 65 & 75 \\
\hline Absorbance & 0.800 & 0.811 & 0.705 & 0.633 & 0.627 & 0.630 & 0.550 \\
\hline
\end{tabular}

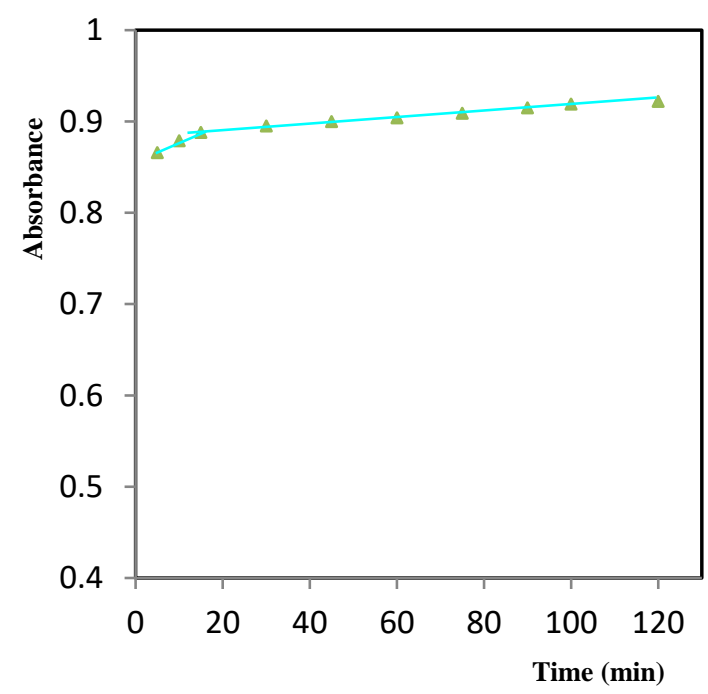

Fig (8): Effect of time on the formation of $\mathrm{Pb}$ (II)-BDFM complex.

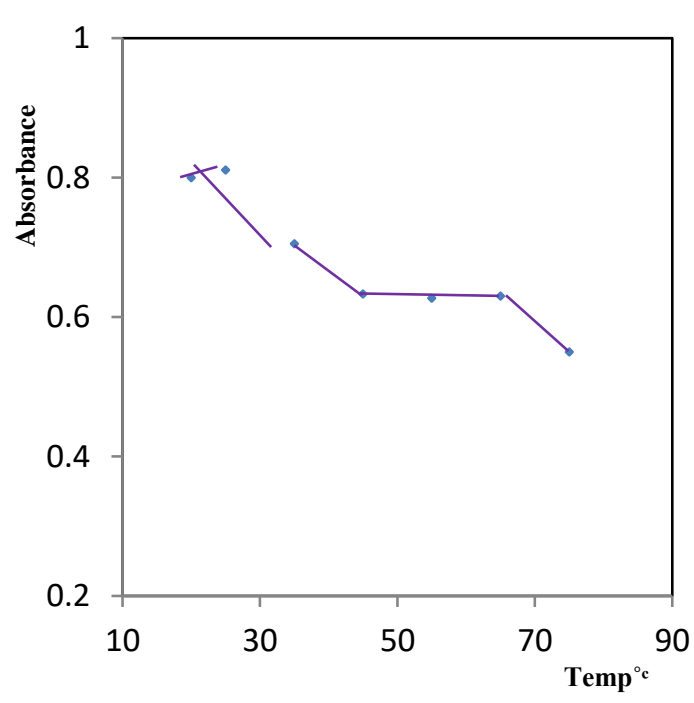

Fig (9): Effect of temperature on the formation of $\mathrm{Pb}$ (II)-BDFM complex.

\section{Determination of the stoichiomertic ratio}

\section{The molar ratio method}

For investigating the molecular structure of the complex formed between, $\mathrm{Pb}$ (II) and BDFM, a series of solutions was prepared in which the metal ion concentration was kept constant at $1.00 \mathrm{~mL}\left(1 \times 10^{-3} \mathrm{M}\right)$, while that of the ligand was regularly varied from 0.1 to $0.8 \mathrm{~mL}$ of $\left(1 \times 10^{-3} \mathrm{M}\right)$. The absorbance of these solutions were measured at $620 \mathrm{~nm}$ with all optimum conditions, and 
then plotted against the molar ratio [ligand] / [metal]. Fig. (10) gave the absorbance - molar ratio curve which showed that $\mathrm{Pb}$ (II) formed a 1:2 complex through the combination with the metal ion as shown in Fig (10).

\section{Using the continuous variation method}

A series of solutions were prepared by mixing an equimolar solution of $\mathrm{Pb}$ (II) and ligand in different proportions from $0.1 \mathrm{~mL}$ to $0.9 \mathrm{~mL}\left(1 \times 10^{-3} \mathrm{M}\right)$ of the same concentration while keeping the total molar concentration constant. A plot of absorbance measured at the recommend wavelength versus mole fraction was used to determine the metal-ligand ratio. Fig. (11) showed that the maximum absorpance obtained at a ratio of 1:2 for the complex.

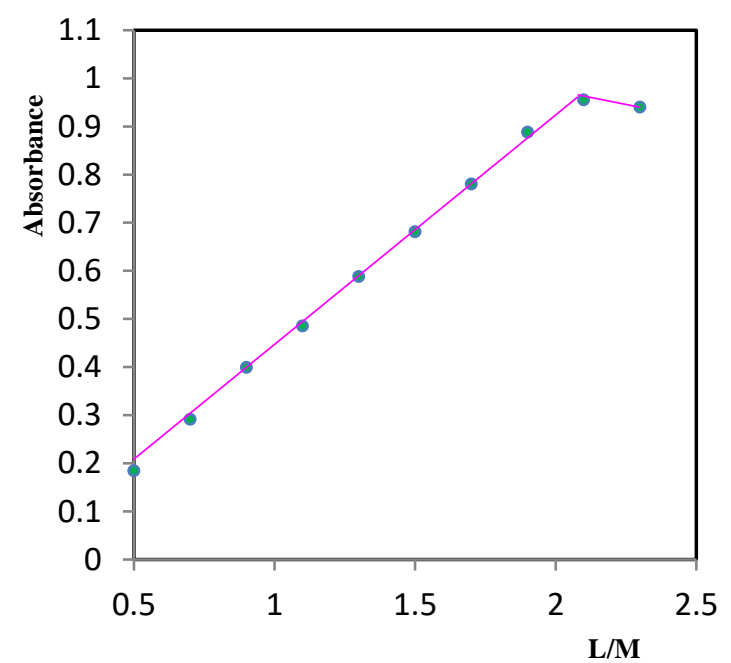

Fig. (10): Determination of the metal- Fig. (11): Determination of the metalreagent ratio of $\mathrm{Pb}$ (II) with $\mathrm{BDFM}$ complexes using molar ratio method.

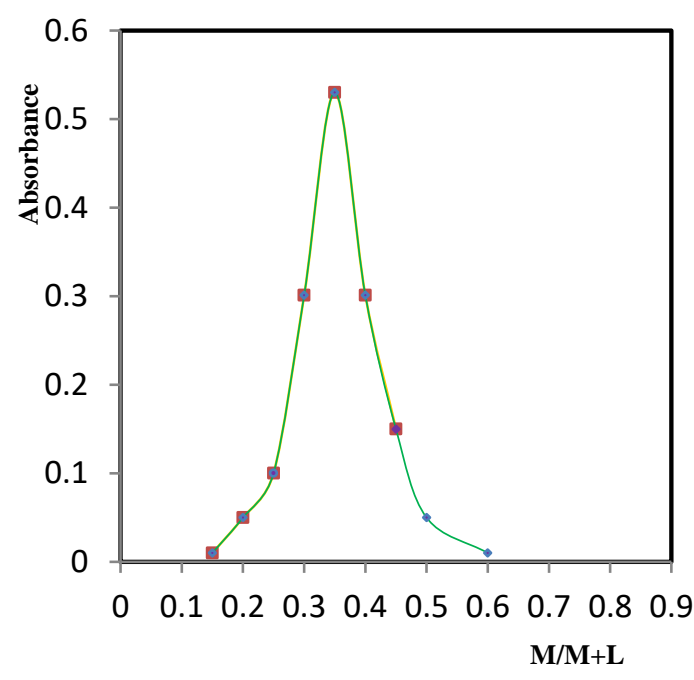

reagent ratio of $\mathrm{Pb}$ (II)with $\mathrm{BDFM}$ complexes using continuous variation method.

\section{Calibration curve}

Several complexes were prepared where the concentration of the ligand was kept constant at $1 \times 10^{-2} \mathrm{M}$ while the concentration of the metal ion was varied from $1 \times 10^{-6}$ to $1 \times 10^{-3} \mathrm{M}$ and their absorbance values were measured versus the concentration of lead (II) at $620 \mathrm{~nm}$ in presence of SLS and other optimum conditions. Beer's law was obeyed from 10 to $110 \mu \mathrm{g} \mathrm{mL}^{-1}$ for $\mathrm{Pb}$ (II), as shown in Fig. (12). 


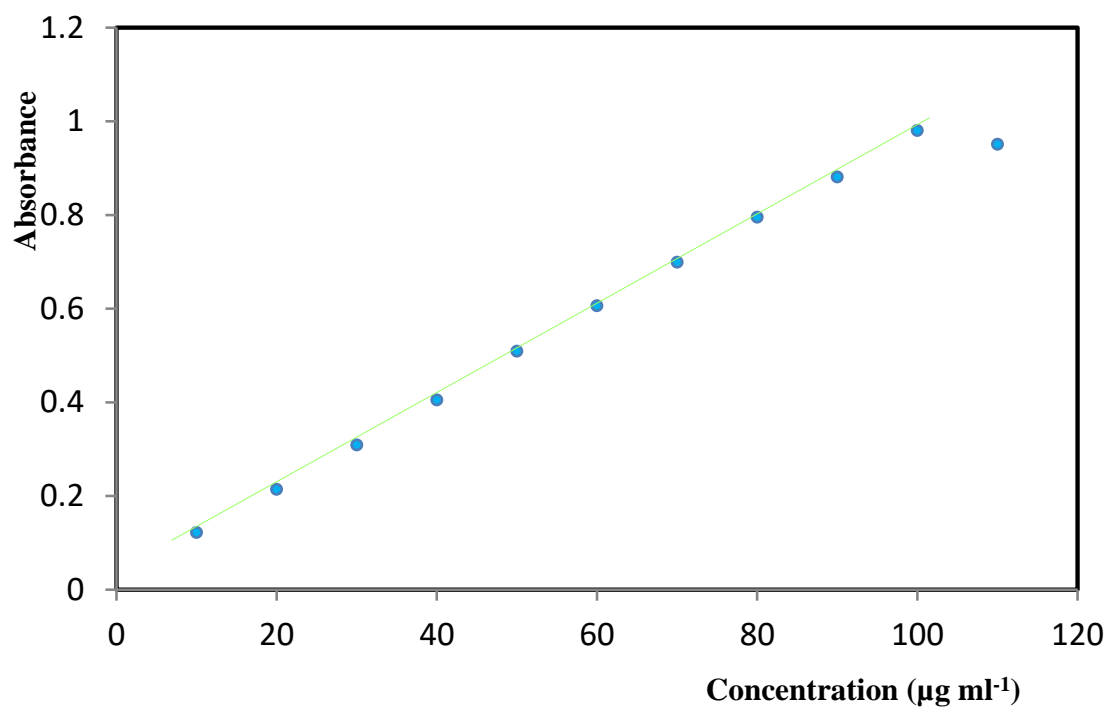

Fig. (12): Calibration curve of $\mathrm{Pb}$ (II) With BDFM complex.

\section{Analytical and statistical characteristics of Pb (II) - BDFM complex}

The molar absorptivity, limit of detection, limit of quantification, relative standard deviation and student t-test were calculated. The data indicates high sensitivity and the good accuracy of the proposed method as showed in the Table-5.

Table-5: Analytical and statistical characteristics of $\mathrm{Pb}$ (II) complex.

\begin{tabular}{|c|c|}
\hline Parameter & Value \\
\hline Molar absorptivity (E) $\mathrm{L} \mathrm{mol}^{-1} \mathrm{~cm}^{-1}$ & $\times 10^{3} 10.16$ \\
\hline Standard deviation $(S D)$ & 0.017320 \\
\hline Relative standard deviation (RSD \%) & 0.0288 \\
\hline Standard error of the mean (SEM) & 0.0065463 \\
\hline Student t-test & 3.3605 \\
\hline Limit of quantification (LOQ) $\mu \mathrm{g} \mathrm{ml}^{-1}$ & 19.2541 \\
\hline Limit of detection (LOD) $\mu \mathrm{g} \mathrm{ml}^{-1}$ & 6.7389 \\
\hline
\end{tabular}

\section{Effect of foreign ions}

The effect of 50 fold molar excess of many species of different cations and anions were tested in the determination of $\mathrm{Pb}$ (II) with Schiff's base ligand. The results showed that as (III), Co (II), W (VI), Cd (II) and Ni (II) interfere in the determination of lead (II) with BDFM.

\section{Application}

The proposed method can be applied for the determination of lead (II) in gasoline, solders and gutters as the above procedures. The results give good and accurate results as shown in table (6). 
Table (6): Determination $\mathrm{Pb}$ (II) in some industrial samples

\begin{tabular}{|c|c|c|c|c|}
\hline Sample & 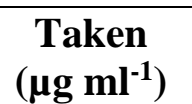 & $\begin{array}{l}\text { Found } \\
\left(\mu \mathrm{g} \mathrm{ml}^{-1}\right)\end{array}$ & $\begin{array}{c}\text { Recovery } \\
\%\end{array}$ & $\begin{array}{c}\text { RSD } \\
\%\end{array}$ \\
\hline \multicolumn{5}{|c|}{ Determination of $\mathrm{Pb}$ (II) in } \\
\hline Gasoline & 11 & 10.88 & 98.90 & 1.1 \\
\hline Solders & 20 & 19.89 & 99.45 & 0.55 \\
\hline Gutters & 24 & 24.40 & 101.66 & 1.66 \\
\hline Wastewater & 11 & 10.88 & 98.90 & 1.1 \\
\hline
\end{tabular}

\section{Conclusion}

New, simple and accurate spectrophotometric method was described for the determination of lead (II) based on the formation of colored complex between the metal ion and the reagent (BDFM). The complex has absorbance maxima at $620 \mathrm{~nm}$ in presence of SLS as a surfactant; with molar absorptivity $10.16 \times 10^{3} \mathrm{~L} \mathrm{~mol}^{-1} \mathrm{~cm}^{-1}$ the complex was stable at room temperature and for a long time. The method was applied for the determination of lead (II) in some industrial samples.

\section{References}

[1] Muhammad Aqeel Ashraf, Karamat Mahmood and Abdul Wajid (2011) Synthesis, characterization and biological activity of schiff bases, International Conference on Chemistry and Chemical Process, vol 10, pp. 1-7.

[2] A.V.G.S. Prasad and P.Venkateswara Rao (2013) Novel synthesis of Schiff base of 4-Nitro Toluene with aldhyde, International Journal of Pharmaceutical, Vol 2, ppl-4.

[3] Sudhir S. Sawant, Vijaya Pawar, Shirish Janrao, Ramesh S. Yamgar and Y. Nivid (2013) Synthesis and characterization of transition metal complexes of novel Schiff base 8-[(z)-\{[3- (N-methyl amino) propyl] imino \}methyl]-7hydroxy-4-methyl-2H-chromen-2one][NMAPIMHMC] and their biological activities, international journal of research in pharmacy and chemistry, vol 3,pp 636-644 .

[4] M. N. Uddin, M. A. Salam, D. A. Chowdhury, J. Sultana and M. E. Halim (2014) Trigonal pyramidal $\mathrm{Pb}$ (II) complexes of schiff bases of Orthoaminophenol: synthesis, characterization, and antibacterial evaluation., International Journal of Advanced Research in Chemical Science, vol 1, pp 47-56.

[5] Zahid Hussien Chohan and Samina Kausar (1992) Biological active complexes nickel, cupper and zinc with schiff base ligand derived from the reaction of 2-Amino pyridine and Pyroll -2-carboxaldhyde_ Their 
synthesis and characterization, Chem. pharm. Bull., vol. 40, pp. 25552556.

[6] Seyed Ali Akbar Sajadi, (2011) A comparative investigation of lead sulfate and lead oxide sulfate study of morphology and thermal decomposition, American Journal of Analytical Chemistry,vol 2, $p p$ 206-211. [7] Le Van Tan (2010) Spectrophotometric determination of lead in environment samples by benzoic acid azo PhenylCalix [4] arene, International Journal of Chemistry, Vol. 2, pp 281-288.

[8] Humaira Khan and M. Jamaluddin Ahmed, (2006) A simple spectrophotometric method for the determination of trace level lead in biological samples in the presence of aqueous micellar solutions, Spectroscopy, vol. 20, pp 285-297.

[9] Yukio Nagaosa and Shinichi Segawa, (1994) Reversed phase HPLC determination of titanium (IV) and iron (III) with sodium 1,2dihydroxybenzene-3,5-disulfonic acid,Journal of Separation Science, Vol 17, pp 770-772.

[10] K. Deepa, Y. Paul raj and Y. Lingappa, (2014) Spectrophotometric determination of lead in medicinal leaf and environmental samples using 5-methylthiophene-2-carboxaldehyde ethylenediamine, Der Pharmacia Lettre, vol 6, pp 380-388.

[11] Raquel B.R. Mesquita, S'ılvia M.V. Fernandes and António O.S.S. Rangel, (2003) A flow system for the spectrophotometric determination of lead in different types of waters using ion-exchange for preconcentration and elimination of interferences, talanta, vol 8, pp 42004272.

[12] Jan krzek, Anna Apola, Mariusz Stolarczyk and Weodzimirez Rzeszutko (2007) Spectrophotometric determination of $\mathrm{Pb}$ (II), Fe(III) and $\mathrm{Bi}(\mathrm{III})$ in complexes with 1,2-diaminocyclohexane-N,N,N', N'tetraacetic acid (DACT), Acta poloniae pharmaceutica - Drug Research, vol. 64, pp. 3-8.

[13] Sabah Shiri, Ali Delpisheh and Ali Haeri (2011) Determination of trace amounts of lead using the flotation-spectrophotometric method, Analytical Chemistry Insights, vol. 6, pp 15-20.

[14] K. Suresh Kumar, K. Suvardhan, B. Lokanath Swaroop and P. Chiranjeevi (2003) Preconcentration of lead using mercaptosephadex and its determination with new reagent by spectrphotometry, Proceedings of the Third International Conference on Environment and Health, Chennai, India, vol 517, pp $252-262$.

[15] O. Ombaka, A. Ndanu, D. I. Kibaara, A. O. Njiri and K. W. Kosgei (2014) Spectrophotometric determination of traces of lead (II) in spinach 
samples marketed in chuka, kenya, International Journal of Modern Chemistry, vol 6, pp 1-17.

[16] Khalaf Faris Alsamarrai (2011) Spectrophotometric assay of lead in human hair samples by using alizarin red in Samarra area, J. of university of Anbar for pure science, vol.5, pp 1-8.

[17] Ankur Ojha, N. Bhojak, Akriti Sharma and Swati Joshi (2015) Indirect micellar spectrophotometric determination of lead in various soybean based products using green chemistry, Asian J. Dairy \& Food Res, vol. 34, pp 239-242.

[18] Ismail M. M. Rahman,,Yoshiaki Furusho, Zinnat A. Begum, Rika Sato, Hiroshi Okumura, Hiroko Honda and Hiroshi Hasegawa (2013) Determination of lead in solution by solid phase extraction, elution and spectrophotometric detection Using 4-(2-Pyridylazo)Resorcinol, Central European Journal of Chemistry, vol 11,pp 672-678.

[19] Humaira Khan and M. Jamaluddin Ahmed (2006) A simple spectrophotometric method for the determination of trace level lead in biological samples in the presence of aqueous micellar solutions, Spectroscopy, vol 20, pp 285-297.

[20] Vogel, A. I. (2002) Text book of Quantitative Inorganic analysis, $6^{\text {th }}$ ed., Pearson.

[21] Britton,H.T.S. (1952) Hydrogen ions, $4^{\text {th }}$ ed.,Chapman and Hall, vol. 28,pp 359-364.

[22] Bower and Bates. (1955) $\mathrm{pH}$ values of the Clark and Lubs buffer solutions at $25^{\circ} \mathrm{c}$, J.Res. Nat1. Bur. Stand., vol 55, pp 197-202.

[23] Lurie,Ju. (1978) Handbook of Analytical Chemistry,2 ${ }^{\text {nd }}$ ed., Mir publishers, Moscow. 


\title{
التقدير الطيفى الاقيق للرصاص الثنائى فى عينات صناعيه بأستخدام 3,1
}

\section{بنزين ثنائى الامين 2- ثنائى فيورنيل ميثيلين فى وجود مواد نشطه سطحيا}

\author{
منير زكى ', علاء أمين ب,خالا الجندى أو أيه جمعه
}

أ قسم الكيمياء كليه العلوم رجامعه الزقازيق ,الزقازيق رمصر

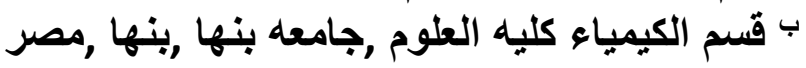

تتميز قو اعد شيف بقدرتها على تكوين منر اكبات ملونه مع ايونات العناصر بطريقه طيفيه. ولوحظ أنه 3,1 بنزين ثنائى الامين 2- ثنائى فيورنيل ميثيلين تكون منراكب بنى اللون مع عنصر الرصاص عند طول موجى 620 نانومنر. وهذا المتر اكب المتكون مع قاعد الثيف يتكون عند الآس الهيدروجينى 3,5 باستخدام محلول منظم من حامض الخليك وخلات الصوديوم وفى وجود ماده نشطه سطحيا وهى صوديوم لوريل سالفيث. وقد تم دراسه تأثير عوامل كل من الوقت ودرجه الحر اره ودر اسة تأثثر الانواع المختلفة من الأيونات والكاتيونات وما قد تسببه من تداخل على تكوين المتر اكب قيد الدراسة. ووجد أن نسبه تكوين المتر اكب المتكون هى 2:1 بأستخدام طريقتى التغير المستمر و النسبه المولاريه. وبتطبيق قانون بيير وجد أن هنالك علاقه خطيه بين الامتصاص ومدى من التركيز تتراوح بين 10-110 ميكروجر ام / مللى كما تم حساب قيمه الامتصاص 10,10×3 لتر/ مول. سم. تم تطبيق الطريقة المقترحة لتقدير الرصاص في البنزين و اللحام و أنابيب الرصاص الخام ومياه الصرف الصحي. 